\title{
Exploring the Benefits of Organic Nutrient Sources for Crop Production and Soil Quality
}

\author{
Carl J. Rosen ${ }^{1}$ and Deborah L. Allan
}

\begin{abstract}
AdDitional INDEX wORDs. organic, nutrient sources, soil quality, health benefits, environment

SUMMARY. Consumer demand for organically grown produce has increased dramatically over the past decade, most likely because of the perceived benefits to the environment and human health. A major component of organic production is providing organic sources of nutrients to promote plant growth as well as sustain soil quality. Organic nutrition of plants can present opportunities and challenges to the grower. The primary objective of this article is to review scientifically based information dealing with the effects of organic nutrient sources on crop yields and quality, soil properties, and environmental risks. Effects of organic nutrient sources are often evaluated by comparison with conventional production, but this approach can be problematic because nutrient source may be confounded with many other cropping system components. Despite these drawbacks, a careful examination of the literature suggests the following conclusions. Soil quality is generally improved with application of organic nutrient sources, but careful management is required to avoid environmental risks of nitrate $\left(\mathrm{NO}_{3}\right)$ leaching and phosphorus accumulation. Provided that nutrient supply is equal, yields with organic sources tend to be similar to those with inorganic sources. However, lack of available nitrogen $(\mathrm{N})$ that is synchronous with plant demand often limits yields in organic cropping systems. Limited $\mathbf{N}$ availability and varied supply of other nutrients from organic sources may contribute to the differences sometimes observed in dry matter content, tissue $\mathrm{NO}_{3}$ and mineral concentration, vitamin $\mathrm{C}$ and other phytochemicals, and taste. Phytonutrient content also may be affected by differences in pest control strategies among cropping systems regardless of nutrient source. There is a slight, but significantly, increased risk of produce contamination by Escherichia coli and other enteric bacteria contamination on produce when organic nutrient sources are used, but if proper guidelines are followed, contamination with the lethal serotype 0157:H7 does not appear to be a major concern. Appropriate management of organic inputs is critical to achieving potential benefits for crop production and soil quality.
\end{abstract}

$\mathrm{T}$ he use of organic farming techniques to grow crops has gained in popularity in recent years as a result of both an increase in consumer demand for organically grown produce and a genuine desire on the part of many growers to sustain or improve the soil (Dimitri and Greene, 2002). Now, organic produce generally commands a higher price than conventional produce (Oberholtzer et al., 2005), prompting producers to grow crops organically. The increased consumer demand appears to be driven primarily by the perception that organically grown produce is safer and more nutritious to eat than produce grown conventionally (Lockie et al., 2002; Williams and Hammitt, 2001).
Department of Soil, Water, and Climate, University of Minnesota, 1991 Upper Buford Circle, St. Paul, MN 55108

${ }^{1}$ Corresponding author. E-mail: rosen006@umn.edu.
Ever since mainstream agriculture switched from more natural nutrient sources such as manure or compost to chemically manufactured synthetic fertilizers over the past 60 to 70 years, there has been much debate about the effect that these nutrient sources have on crop and soil quality. In a review over 30 years ago on this subject, Barker (1975) concluded that both organic and synthetic fertilizers have a role in agriculture and the good points of each should be acknowledged. Before and since that time, many studies have been conducted in an attempt to quantify differences in crop and soil attributes resulting from conventional and organic production methods.
Numerous problems exist when comparing nutrient sources in organic and conventional systems, mainly because of the difficulty in controlling all the variables involved (Hornick, 1992; Lester, 2006). Controlling variables is difficult because organic production methods have a defined set of rules to follow [U.S. Department of Agriculture (USDA), 2000], meaning that differences between systems include more factors than just nutrient source. Unless experiments are designed carefully, comparing systems can lead to results in which nutrient source is confounded with: unequal rates or availability of the nutrient(s) in question, methods for controlling weeds, differences in crop rotations, insects and diseases, cultivar, climate, stage of harvest, and postharvest handling. From a practical or consumer standpoint, it may not matter what the exact causes of the differences are, but from a production or scientific standpoint, it is important to know what components of the system may exert an influence on crop and soil quality.

The focus of this review is on organic nutrient sources used in organic production, but these sources can also be a component of conventional production. We define, but do not limit, organic nutrient sources acceptable for organic production as natural, carbon (C)-containing, free from prohibited substances, nonsynthetic materials such as fresh or composted plant and animal material and green manures or cover crops grown in place. Nonsynthetic inorganic materials that have not been processed chemically such as crushed rock phosphate, limestone, various potassium $(\mathrm{K})$ minerals, and other rock or mineral products may also qualify as nutrient sources acceptable for organic production. Not surprisingly, most of the research reported in the literature compares manures or composts and legume-based cropping systems with conventional fertilizer systems.

Some of the questions that we explore include the following: Are there benefits of one system over the

\begin{tabular}{|c|c|c|c|}
\hline \multicolumn{4}{|l|}{ Units } \\
\hline $\begin{array}{l}\text { To convert U.S. to SI, } \\
\text { multiply by }\end{array}$ & U.S. unit & SI unit & $\begin{array}{l}\text { To convert SI to U.S., } \\
\text { multiply by }\end{array}$ \\
\hline $\begin{array}{l}1.1209 \\
2.2417\end{array}$ & $\begin{array}{l}\mathrm{lb} / \mathrm{acre} \\
\text { ton/acre }\end{array}$ & $\begin{array}{l}\mathrm{kg} \cdot \mathrm{ha}^{-1} \\
\mathrm{mg} \cdot \mathrm{ha}^{-1}\end{array}$ & $\begin{array}{l}0.8922 \\
0.4461\end{array}$ \\
\hline
\end{tabular}


other for improved soil properties, more nutritious produce with better taste, or fewer environmental problems? What benefits can be truly attributable to the nutrient source? A number of recent reviews comparing the effects of conventional and organic production systems on health aspects and nutritional quality of foods have been written (Bourn and Prescott, 2002; Brandt and Molgaard, 2001; Chen, 2005; Heaton, 2001; Magkos et al., 2003; Trewavas, 2004; Williams, 2002; Woese et al., 1997; Worthington, 2001; Zhao et al., 2006). The intent of this article is to complement those reviews and take a broader view of organic plant nutrient sources by assessing soil and crop quality aspects of the different crop management systems. The overall objective of this review is to provide insights into potential benefits as well as challenges of using organic nutrient sources for crop production based on research and previous reviews reported in the scientific literature.

\section{Soil properties}

The beneficial effects of organic matter on soil physical, chemical, and biological properties have been known for many years. Maintaining or increasing soil organic matter levels can improve aggregation of soil particles, which in turn results in better drainage, infiltration, and tilth. Organic matter acts as a slow-release form of crop nutrients and is a source of energy and nutrients for soil microbes. Amounts of soil organic matter are affected by tillage practices, crop rotations, use of green manures, and inputs of organic residues, manure, and compost.

The benefits of rotation and legumes were demonstrated in a 13-year study initiated in the 1930s comparing continuous corn (Zea mays), continuous alfalfa (Medicago sativa), clean fallow, and a cornwheat (Triticum aestivum)-clover (Trifolium spp.) rotation (Uhland, 1947). Soil organic matter increased with the alfalfa crop, stayed the same with the three-crop rotation, and decreased with the continuous corn and clean fallow treatments. In a more recent study comparing three systems, higher soil C levels were obtained with legumes in the rotation and manure additions than with a similar rotation using conventional fertilizer additions but without legumes or one with legumes and no manure additions (Clark et al., 1998). When manure additions were discontinued, soil $\mathrm{C}$ decreased over the subsequent 4 years, resulting in similar soil $\mathrm{C}$ concentrations among all three systems. Drinkwater et al. (1998) also found that soil $\mathrm{C}$ and nitrogen (N) concentrations increased in manure and legume-based organic systems more than in a conventional system, although amounts of $\mathrm{C}$ inputs were as high or higher in the conventional system. They suggested that differences in the quality of the inputs ( $\mathrm{C}: \mathrm{N}$ ratio and lignin content) in the organic systems were a factor in greater retention of $\mathrm{C}$ and N. Some studies have attempted to quantify the quality of organic inputs for various systems using $\mathrm{N}$, lignin, and polyphenol content of the inputs (Palm et al., 2001; Vanlauwe et al., 2005). These parameters appear useful for predicting short-term $\mathrm{C}$ and $\mathrm{N}$ mineralization, but more research is needed to evaluate their long-term effect on maintenance of soil organic matter.

In a summary of 14 long-term animal manure studies, Edmeades (2003) concluded that manured soil had higher organic matter levels, lower bulk density, higher porosity and hydraulic conductivity, and greater aggregate stability than soils fertilized conventionally. Improvements in all of these soil quality indicators will optimize crop growth (Karlen and Stott, 1994; Yoder, 1937). Thus, one of the most significant benefits of manure as an organic nutrient source is the potential to maintain or increase soil organic matter levels. However, the practice of applying manure to fields not involved with animal agriculture is at the expense of harvesting nutrients from elsewhere. Edmeades' review (2003) also addressed environmental concerns associated with manure application and these are discussed in a later section.

Other long-term studies have shown soil quality improvements with organic management. Pulleman et al. (2003) compared an arable organic system with an arable conventional system and a permanent pasture system. All systems had been under their respective management for at least 70 years. Tillage in either the organic or conventional system resulted in lower soil organic matter content, mineralization, earthworm (Lumbricus spp.) activity, and water stable aggregates than in soils of the permanent pasture. However, for all these parameters, values were greater under the organic system than in the conventional system. In a long-term cropping systems trial at Lamberton, $\mathrm{MN}$, a 4-year organic corn-soybean (Glycine max)-oat (Avena sativa)/ alfalfa-alfalfa rotation that received manure inputs had higher amounts of total organic $\mathrm{C}$ and labile $\mathrm{C}$ and $\mathrm{N}$ pools than the high-input conventional system, but microbial biomass and total organic matter was the same as in the conventional system with reduced tillage (Kuratomi, 2003). Thus, organic inputs can help compensate for the losses in soil organic matter incited by intensive tillage and may be particularly beneficial in systems in which intensive tillage is used to control weeds.

Microbial biomass and labile organic matter pools are often greater in organic than conventionally managed soils. Higher organic matter content, $\mathrm{N}$ mineralization potential, and microbial biomass were observed in organically farmed plots than in those receiving commercial fertilizers (Power and Doran, 1984). In a comparison of five certified organic and conventional farm pairs, Liebig and Doran (1999) found greater total C and $\mathrm{N}$, microbial biomass, soil respiration, and mineralizable $\mathrm{N}$ in organically managed farms than in conventional farms. In a German study, researchers compared length of time under organic management (Friedel and Gabel, 2001). On farm plots where soils had been under organic management for 3,9 , or 41 years, microbial biomass increased significantly over time, but total C and $\mathrm{N}$ and potentially mineralizable $\mathrm{N}$ in the organic farm of each pair did not change. The relationship between soil microbial populations and crop growth is not clearly understood and is an area of ongoing research (Kennedy, 1999).

\section{Crop yield}

Assessment of yield as affected by organic-nutrient sources can be problematic because these sources are complex compounds with varying 
degrees of nutrient availability and unpredictable release rates. Better characterization of organic input chemical constituents may help predict short-term mineralization rates (Palm et al., 2001; Vanlauwe et al., 2005), but the process will still vary with weather conditions such as rainfall and temperature. Based on the longterm evaluation of 14 sites receiving either manure or fertilizer, yields obtained with manure were generally similar to those obtained with conventional fertilizer except for one site where yields were higher with manure (Edmeades, 2003). Despite the beneficial effects of manure on soil quality noted previously, use of conventional fertilizer can apparently compensate for less desirable soil conditions such as lower organic matter. Provided that nutrient supply is equal or at adequate levels to support growth, yields with organic sources tend to be similar to those with inorganic sources.

A 21-year trial in Europe comparing organic and conventional systems found that yield in the organic systems was only $20 \%$ to $40 \%$ lower than in conventional systems although nutrient inputs were 34\% to $51 \%$ lower (Mader et al., 2002). Although yields were limited by nutrients and diseases, the authors suggested that organic systems tend to be more efficient than conventional systems, presumably as a result of enhanced microbial activity or because of buildup of organic nutrient pools (Langmeier et al., 2002). The conclusion by Mader et al. (2002) that organic systems may be more efficient has also come into question (Trewavas, 2004). Goklany (2002) noted that more land would be required to produce equivalent yields, which could offset the gains in efficiency. In addition, the greater nutrient use efficiency may not be solely the result of the organic farming system, because lowering nutrient inputs even in conventional systems can result in more efficient use of nutrients (Halvorson and Reule, 2006; Zebarth et al., 2004; Zvomuya et al., 2002).

Clark et al. (1999) reported that $\mathrm{N}$ availability was often the most important factor limiting yield in organic tomato (Solanum lycopersicum) systems; although, by including proper cover crops and using composts, comparable yield could be achieved. In cases in which deficiency was noted, a lack of synchrony between $\mathrm{N}$ release from organic sources and demand by the crop is the probable cause (Kirchmann and Ryan, 2004; Pang and Letey, 2000). High-value horticultural crops may allow the purchase of more readily mineralizable forms of organic $\mathrm{N}$ sources or, if available, the use of more land to grow green manure crops to ensure that $\mathrm{N}$ is not lacking. However, there is potential for higher $\mathrm{N}$ losses and soil phosphorus (P) loading when more readily available $\mathrm{N}$ sources such as manure are used. Environmental consequences of high $\mathrm{N}$ availability and management practices to reduce the potential losses are discussed in a later section.

\section{Produce quality}

A number of recent reviews have been published on the effects of organic production systems on produce quality (Bourn and Prescott, 2002; Brandt and Molgaard, 2001; Chen, 2005; Heaton, 2001; Magkos et al., 2003; Williams, 2002; Woese et al., 1997; Worthington, 2001; Zhao et al., 2006). In most cases, these reviews cited studies that compared composition of organically produced crops with those conventionally produced. As discussed, many of the comparisons were confounded, and definitive conclusions are difficult to make. Bourn and Prescott (2002), Zhao et al. (2006), and Lester (2006) pointed out numerous problems with some of the studies and concluded that further research was needed using carefully designed experiments. Despite the problems involved, a number of effects are listed consistently as being attributable to organic production systems and directly or indirectly to organic nutrient sources. Reported benefits of produce from organic systems include: higher dry matter content, higher mineral concentrations, lower nitrate $\left(\mathrm{NO}_{3}\right)$ concentrations, higher vitamin $\mathrm{C}$ concentrations, higher phytonutrient content, and better taste. Each of these is discussed briefly subsequently in relation to nutrient source.

In general, tissue dry matter content was reported to be higher in organically grown leafy vegetables, but not in fruit (Magkos et al., 2003; Woese et al., 1997). Heaton
(2001) reported that 10 of 19 studies showed that dry matter of produce from organic systems was higher than in conventionally grown produce. Increasing $\mathrm{N}$ rate (either from manure or synthetic fertilizers) generally promotes higher yield and dry matter accumulation on a per-plant basis (Stanford and Legg, 1984). However, as a result of limited $\mathrm{N}$ availability, Leclerc et al. (1991) reported that organically grown produce weighed less on a per-plant basis than conventionally grown produce but had higher dry matter content and less water. High rates of $\mathrm{K}$ fertilization have been reported to reduce dry matter content in some crops (Allison et al., 2001). It is likely that lower plant weight and higher dry matter content in some organically grown plants is related to lower soil $\mathrm{N}$ and possibly lower soil $\mathrm{K}$ availability than with conventional systems.

Elemental concentrations in plant tissue are affected by plant species, dry matter production, and level of available nutrients in the soil. Total uptake of a nutrient by the plant can be the same, but a higher dry matter content may dilute some elements on a concentration basis. Any factor affecting dry matter production and nutrient uptake and accumulation can alter the concentration in the plant. Most of the studies reviewed found no clear trend in tissue elemental concentrations as a result of nutrient source, although Worthington (2001) reported that many studies found $\mathrm{P}$, magnesium $(\mathrm{Mg})$, and iron $(\mathrm{Fe})$ higher in organic systems, and Heaton (2001) concluded that "mineral nutrients are on average higher in organically grown crops; although, ...more research is needed to confirm this finding." Heaton (2001) also commented on the fact that many studies reported nutrient concentrations on a dry matter basis when, in fact, for most fruit and vegetables, concentration on a fresh matter basis would be more useful. Given that many composts and manures tend to have lower $\mathrm{N}$ and $\mathrm{K}$, but higher $\mathrm{P}$, secondary, and micronutrients relative to plant demand, it is quite possible that use of manure and compost over time might tend to increase tissue $\mathrm{P}$, secondary, and micronutrients compared with conventionally fertilized systems. In addition, composts and manures can stimulate 
chelate-producing microorganisms and could affect uptake of micronutrients such as $\mathrm{Fe}$ (Chen et al., 1998).

Although debate occurs over the health risks of $\mathrm{NO}_{3}$ in the diet, it is generally accepted that high levels of $\mathrm{NO}_{3}$ can cause methemoglobinemia in infants. In addition, some correlation exists between certain types of cancer and high $\mathrm{NO}_{3}$ in the diet (Santamaria, 2006). Many of the reviews noted that, on average, $\mathrm{NO}_{3}$ levels tended to be higher in conventionally grown produce (Bourn and Prescott, 2002; Chen, 2005; Heaton, 2001; Williams, 2002; Woese et al., 1997; Worthington, 2001). Factors affecting $\mathrm{NO}_{3}$ levels in plant tissue depend on plant species or cultivar, soil $\mathrm{N}$ availability, rate and timing of $\mathrm{N}$ fertilizer, environmental conditions such as soil moisture, temperature, and light, stage of growth, and season (Maynard et al., 1976; Santamaria et al., 2001). In a study reported by Termine et al. (1987), $\mathrm{NO}_{3}$ concentrations in leek (Allium ampeloprasum Porrum group) and turnip (Brassica rapa var. rapa) were lower in plants grown in composttreated pots than in those receiving $\mathrm{N}-\mathrm{P}-\mathrm{K}$ fertilizer. However, in plants receiving blood meal, a readily available organic $\mathrm{N}$ fertilizer source, the $\mathrm{NO}_{3}$ levels were similar to those receiving $\mathrm{N}-\mathrm{P}-\mathrm{K}$ fertilizer. Maga et al. (1976) reported that a low rate of ammonium sulfate $\left[\left(\mathrm{NH}_{4}\right)_{2} \mathrm{SO}_{4}\right]$ fertilization produced similar yields to a higher rate of blood meal fertilization, but $\mathrm{NO}_{3}$ concentrations were actually lower in plants fertilized with $\left(\mathrm{NH}_{4}\right)_{2} \mathrm{SO}_{4}$. Nitrate concentrations in spinach (Spinacia oleracea) and lettuce (Lactuca sativa var. capitata) leaves were lower in plants receiving composted manure compared with those receiving $\mathrm{N}-\mathrm{P}-\mathrm{K}$ fertilizer (Vogtmann et al., 1984). However, vegetable yields were generally lower for those crops grown with compost than with synthetic fertilizer and cultivar differences also were evident. Harwood (1984) reported lower $\mathrm{NO}_{3}$ concentrations in leaves of pak choi (Brassica rapa var. chinensis) when fertilized with fermented chicken manure than with $\mathrm{NH}_{4} \mathrm{NO}_{3}$ without yield suppression as a result of source. A general conclusion here is that $\mathrm{NO}_{3}$ levels in vegetables tend to be lower when grown with composted manure or green manure.
However, $\mathrm{NO}_{3}$ levels may be just as high in organic systems as conventional systems if rapidly available $\mathrm{N}$ sources such as blood meal or noncomposted manure are used. More research is needed in certified organic systems to evaluate $\mathrm{NO}_{3}$ levels in plant tissue when noncomposted manure and other sources are used according to certification guidelines.

Of the organic constituents measured in plant tissue, ascorbic acid (vitamin C) has frequently been reported, on average, to be higher in organically grown plants than with plants grown conventionally (Chen, 2005; Heaton, 2001; Williams, 2002; Woese et al., 1997; Worthington, 2001). However, studies could be found in which there were no differences resulting from source (Brandt and Beeson, 1951; Lombardi-Boccia et al., 2004; Nilsson, 1979), or in some cases, ascorbic acid was lower in produce grown with organic sources (Lester, 2006; Montagu and Goh, 1990). Factors affecting ascorbic content include cultivar, $\mathrm{N}$ rate, environmental factors (especially light), stage of growth, and storage (Dumas et al., 2003; Hamner et al., 1945). Oxidative stresses such as drought, full sunlight, and low $\mathrm{N}$ availability also have been reported to increase ascorbic acid content (Brandt and Molgaard, 2001).

Increasing $\mathrm{N}$ rate regardless of source or form tended to decrease concentration of ascorbic acid in tomato (Montagu and Goh, 1990). In that study, increasing compost rate decreased ascorbic acid concentration to a greater degree than $\mathrm{NO}_{3}$ or $\mathrm{NH}_{4}$ fertilizer sources, despite lower yields with the compost treatment. Opposite results were reported by Harwood (1984) in which ascorbic acid content was higher in pak choi supplied with compost than in those supplied with $\mathrm{NH}_{4} \mathrm{NO}_{3}$. An inverse relationship between pak choi tissue $\mathrm{NO}_{3}$ and ascorbic acid concentration was reported. Termine et al. (1987) found no relationship between tissue $\mathrm{NO}_{3}$ and ascorbic acid in leeks and turnips. In a more recent study with tomatoes conducted in the greenhouse with sand culture, Toor et al. (2006) compared three $\mathrm{NO}_{3} / \mathrm{NH}_{4}$ treatments (4:1 with $\mathrm{SO}_{4}$ as the dominant anion, $1: 4$ with chloride as the dominant anion, and 1:4 with $\mathrm{SO}_{4}$ as the dominant anion) with two organic treatments: chicken manure and grass-clover mulch. Yield of fruit per plant was unaffected by treatment, but shoot mass per plant was significantly lower if plants were supplied with the organic sources than with the various inorganic $\mathrm{N}$ sources. The lower shoot biomass with the organic sources suggests lower $\mathrm{N}$ availability. Ascorbic acid content of the tomato fruit was significantly lower in the 4:1 $\mathrm{NO}_{3} / \mathrm{NH}_{4}$ treatment than with the $1: 4 \mathrm{NO}_{3} / \mathrm{NH}_{4}$ treatments or the organic treatments. One hypothesis for $\mathrm{N}$ source effects suggested by Toor et al. (2006) is that the higher $\mathrm{N}$ with inorganic sources increased vegetative growth and caused more shading of fruit, thereby lowering the ascorbic acid content (Dumas et al., 2003; Hamner et al., 1945). This hypothesis, however, does not address why the ascorbic acid contents varied with amounts of $\mathrm{N}$ supplied as $\mathrm{NO}_{3}$ or $\mathrm{NH}_{4}$ suggesting further research is needed.

Interest in other plant secondary compounds has increased because of their potential effects on improving human health (Dumas et al., 2003). For example, phenolic compounds, which play a role in plant defense mechanisms to resist diseases and insects, also act as antioxidants if consumed in food. Higher levels of phenolic compounds frequently have been reported in organically grown crops than in conventionally grown crops (Carbonaro et al., 2002; Lombardi-Boccia et al., 2004; Sousa et al., 2005). Like with ascorbic acid, the results reported are often inconsistent and at times contradictory. The role of organic nutrient sources in production of plant phenolic compounds is now unclear, but current evidence suggests that factors other than nutrition may be primarily involved. Results reported by Young et al. (2005) with leafy vegetable crops have shown that the organic systems sometimes provide an opportunity for insect attack, which can result in a higher level of phenolic compounds. In the study discussed by Toor et al. (2006) in which ascorbic acid content in tomatoes was lowest in plants receiving $\mathrm{NO}_{3}$ as the dominant $\mathrm{N}$ form, there was no difference in soluble phenolics resulting from treatment, and lycopene was higher in $\mathrm{NO}_{3}$-fed plants than with plants provided with organic nutrient 
sources. This study was conducted in the greenhouse and was not a comparison of organic systems. Therefore, pest control would have been uniform for the study. A recent study by Zhao et al. (2007) found that phenolic compounds in lettuce were not consistently affected by nutrient source. In that study, numerous factors, including growing environment, season, and cultivar, affected phenolic compounds with cultivar differences being most significant.

Taste test panels have been used in a number of studies to determine if organically grown produce tastes differently than conventionally grown produce. In most studies reported, nutrient source is confounded with pest control making it difficult to draw conclusions. Schutz and Lorenz (1976) found no consistent differences between vegetables produced with organic amendments and those grown conventionally. For lettuce and green bean (Phaseolus vulgaris), there was no difference resulting from growing system, but for carrot (Daucus carota), the produce from the conventional system was preferred over organic, and for broccoli (Brassica oleracea var. italica), there was a preference for produce from the organic system. In a study with potato (Solanum tuberosum), taste panel members rated organically grown potatoes as being more bitter than those grown conventionally when tasted with skins on the potato (Wszelaki et al., 2005). If skins were removed, no difference in taste occurred between the organic and conventional systems. In that study, potatoes grown organically had two times more glycoalkaloids than those grown conventionally, and skins had 100 times more glycoalkloids than the flesh. Reasons for higher glycoalkaloids in organically grown potatoes were not provided in the report; however, the effect could be the result of more insect stress (Hlywka et al., 1994) or perhaps more light exposure to the skins in the organically grown potatoes (Dale et al., 1993). Using tomatoes grown with various $\mathrm{NO}_{3}: \mathrm{NH}_{4}$ ratios and organic treatments as described for ascorbic acid differences, Heeb et al. (2005) found that those grown with higher $\mathrm{NH}_{4}$ nutrition and organic nutrient sources rated higher in taste tests than those grown primarily with $\mathrm{NO}_{3}$ nutrition. Analysis by Toor et al. (2006) revealed that tomatoes from plants grown with $\mathrm{NO}_{3}$ as the primary $\mathrm{N}$ form had lower titratable acidity and higher $\mathrm{pH}$ than those grown with organic $\mathrm{N}$ sources or $\mathrm{NH}_{4}-\mathrm{N}$ forms. Based on the available literature to date, the taste of produce is affected by many factors sometimes favored by organic production systems and sometimes not.

\section{Environmental and health challenges}

Whether organic nutrient sources are more environmentally friendly than conventional sources in terms of reduced $\mathrm{P}$ runoff or $\mathrm{NO}_{3}$ leaching depends on management practices such as rate applied, timing of application, and methods of incorporation (Magdoff, 1991). Relatively high rates of organic amendments are needed to increase soil organic matter and provide available nutrients. For example, to raise organic matter content by $1 \%$, $\approx 50 \mathrm{Mg} \cdot \mathrm{ha}^{-1}$ dry weight of organic inputs would need to be applied. This calculation is based on the assumption that residue $\mathrm{C}$ entering the soil organic matter pool may be only $10 \%$ to $20 \%$ of the $\mathrm{C}$ in the original residue (Wolf and Wagner, 2005). Because $\mathrm{N}$ is usually the most limiting nutrient for crop production, application of organic nutrient sources such as manure and compost are usually based on estimated available $\mathrm{N}$. However, the relatively low $\mathrm{N}: \mathrm{P}$ ratio of most manure and compost amendments as well as high amounts of trace elements relative to crop removal can result in soil accumulation of $\mathrm{P}$ as well as certain trace elements such as zinc and copper. In Edmeades' review of long-term manure trials (2003), he found that topsoils were highly enriched in $\mathrm{P}$, as well as $\mathrm{K}$, calcium, and $\mathrm{Mg}$. Plant growth and production are not generally affected by high $P$ accumulation, but if runoff or erosion occurs, there is the potential for degradation of surface water bodies. Loading of soil $\mathrm{P}$ is more severe with compost applications than with fresh manure applications because during the composting process, inorganic $\mathrm{N}$ becomes less available and $\mathrm{P}$ concentrations increase (Larney et al., 2006; Spargo et al., 2006). Over a 15-year period, theoretical loading of $\mathrm{P}$ based on application of $\mathrm{N}$ at $150 \mathrm{~kg} \cdot \mathrm{ha}^{-1}$ from compost was over 10 times greater compared with noncomposted manure (Magdoff and Weil, 2004). Excessive loading of $P$ as well as trace elements has been documented with continuous use of poultry manure compost on organic farms (Mikkelsen, 2000). This highlights the importance of soil and organic input analysis to help guide application of organic amendments. In situations with very high soil $P$, estimated available $\mathrm{N}$ should not be used as the basis for application rates.

In some cases, the improvement in soil physical properties from compost application can compensate for the increases in $\mathrm{P}$ so that the $\mathrm{P}$ lost does not differ between composttreated and conventionally fertilized plots. In a study comparing application of composted poultry litter to commercial fertilizer and fresh poultry litter, Spargo et al. (2006) showed that risk of $\mathrm{P}$ loss in runoff during rainfall simulations was half as much with the composted poultry litter because of improvements in infiltration. This study did not address the potential of $\mathrm{P}$ losses through leaching, although the assumption is that these losses would be low.

There are management options to help reduce accumulation of soil $\mathrm{P}$ and trace elements with application of organic nutrient sources. One is to use legume green manures in the rotation to supply $\mathrm{N}$ rather than to use farm manure or compost. Various legumes can provide part of or all of the $\mathrm{N}$ required for subsequent crops through natural $\mathrm{N}$ fixation without increasing soil P. With crop removal, soil $\mathrm{P}$ as well as other nutrient levels will gradually decrease. This approach may be useful for orchards or vineyards where cover crops are normally planted between rows, but for annual crops, it does decrease the amount of land available for production (Crews and Peoples, 2004). In addition, attempts to use various plant species to lower soil $\mathrm{P}$ concentrations in annual cropping systems have so far been met with limited success (Alsup et al., 2002; Novak and Chan, 2002). Ideally, application of manure or compost should be based on the nutrient with the most potential for environmental risk. In most cases, this will be P (Magdoff, 1991). Another approach is to use organic $\mathrm{N}$ sources with low P contents such as blood 
meal or soybean meal. However, the high cost of these fertilizers makes their use impractical for all but the highest value crops. For more specific information on managing $\mathrm{N}, \mathrm{P}$, and $\mathrm{K}$ sources for organic production, refer to Gaskell and Smith (2007), Nelson and Janke (2007), and Mikkelsen (2007).

Another environmental concern associated with manure or compostbased organic nutrient sources is the potential for $\mathrm{NO}_{3}$ leaching to groundwater. Kirchmann and Bergstrom (2001) concluded that $\mathrm{NO}_{3}$ leaching can be lower with organic nutrient sources than with conventional nutrient sources if inputs into the system are lower or if high $\mathrm{C}: \mathrm{N}$ amendments are used. In most cases, however, yields will suffer. Nitrate leaching with organic nutrient sources is usually either similar to or greater than conventional sources when high rates of manure or compost are applied. The main cause of the leaching in organic systems was the result of an asynchrony of crop demand and $\mathrm{N}$ release from the organic nutrient sources (Kirchmann and Ryan, 2004).

Either fertilized (organic or inorganic inputs) or legume-based cropping systems can result in $\mathrm{NO}_{3}$ leaching depending on management. Edmeades (2003) found elevated levels of $\mathrm{NO}_{3}-\mathrm{N}$ in the subsoils of the 14 manure trials he examined. In legume-based systems, risks of losses are greatest when legumes are incorporated and the land is fallow long enough to allow mineralization to occur before the subsequent crop is established. In contrast, where legumes grow throughout the fallow season, they can both fix and scavenge $\mathrm{N}$ and reduce $\mathrm{NO}_{3}$ leaching risk provided that the nitrate levels are not high enough to suppress nitrogen fixation (Crews and Peoples, 2004). In a Swedish study, Torstensson et al. (2006) found that leaching loads over a 6-year period were smallest in a conventional system with cover crops $\left(25 \mathrm{~kg} \cdot \mathrm{ha}^{-1}\right.$ per year $\left.\mathrm{N}\right)$ and similar in the conventional, organic with animal manure, and organic without animal manure systems $(38,39$, and 34 $\mathrm{kg} \cdot \mathrm{ha}^{-1}$ per year $\mathrm{N}$, respectively). In contrast, $\mathrm{NO}_{3}$ leaching was $\approx 5$ times higher in conventionally fertilized plots than plots with organic inputs (1350 versus $275 \mu \mathrm{g} \mathrm{NO}-\mathrm{N}$ at $1 \mathrm{~m}$ depth, measured with resin bags) in an experimental apple (Malus pumila) orchard (Kramer et al., 2006). Careful management of manure or legumes in organic cropping systems reduced $\mathrm{NO}_{3}$ losses than with conventionally fertilized systems (Drinkwater et al., 1998). In that study, over 10 years of cropping using low $\mathrm{C}: \mathrm{N}$ organic residues (manure or legumes) combined with a more diverse cropping system resulted in 30\% lower $\mathrm{N}$ losses compared with a conventionally fertilized corn/soybean system. Over the same time period, average yields and profitability of the organic system were reported to be comparable with the conventional system. These results show that it is possible to maintain soil fertility and yields in an organic system with careful management while reducing $\mathrm{N}$ losses.

One potential risk for people consuming produce grown with manure or manure-based composts is an increased exposure to enteric pathogens (Buck et al., 2003). The bacteria of concern are Escherichia coli, Salmonella spp., and Listeria monocytogenes. E. coli and Salmonella are in animal gastrointestinal tracts and consequently in manure, whereas L. monocytogenes is in decaying plant residues, soil, and animal manure. Consumption of produce contaminated with the E. coli serotype O157:H7 can in some cases cause death in people with weak immune systems. Numerous outbreaks of gastrointestinal disease have been linked to consumption of fresh fruit and vegetables; however, the source of contamination can occur at various stages of production through actual sale of the final product. Although organic nutrient sources are not the only source of bacterial contamination, precautions in handling manure and manure compost need to be taken. To reduce the risk of contaminated produce, certified organic methods require that manure applied to fields must either be properly composted before application or produce for human consumption cannot be harvested for at least $90 \mathrm{~d}$ after application for edible portions of the crop not in direct contact with the soil and $120 \mathrm{~d}$ for edible portions in direct contact with the soil (USDA, 2000 ). Specific procedures that maintain temperatures in the pile to kill the pathogens must be followed during the composting process.
In a survey of 32 farms using organic nutrient sources and eight farms using conventional nutrient sources in Minnesota, Mukherjee et al. (2004) reported that produce from $1.9 \%$ of the farms using only inorganic nutrient sources tested positive for $E$. coli, whereas produce from $9.7 \%$ of the farms using organic nutrient sources tested positive, a statistically significant finding. In that study, results from certified and noncertified farms using organic sources were initially combined. Of the farms that used organic nutrient sources, produce from $4.3 \%$ of the organically certified farms tested positive, a value that was not statistically different from farms using inorganic nutrient sources. The serotype O157:H7 was not detected in any of the produce. Salmonella was isolated from one lettuce sample and one pepper (Capsicum annuum Grossum group) sample, both from an organic farm. In a follow-up study, Mukherjee et al. (2006) analyzed fruit and vegetables produced on conventional (any practice acceptable), semiorganic (used organic practices but were not certified), and organic (certified by USDA-accredited organic certification agency) farms for prevalence of E. coli, E. coli O157:H7, and Salmonella. Over the 2-year study, none of the produce samples were contaminated with E. coli O157:H7 or Salmonella. Prevalence of $E$. coli on produce grown on the three farm types was only statistically different for leafy greens. Contamination of leafy greens produced on semiorganic farms was higher than that of leafy green produced on organic farms. Contamination was influenced more by produce type than farm type. Loncarevic et al. (2005) reported that $8.9 \%$ of 179 organically grown lettuce samples collected from 12 producers in Norway were contaminated with $E$. coli, but only $2.2 \%$ of the samples were considered to have high enough levels to cause foodborne illness. The serotype O157:H7 and Salmonella were not detected in any of the samples. Listeria monocytogenes serogroups 1 and 4 were isolated from $1.1 \%$ of the samples. In a study to determine the potential for contamination with $E$. coli serotype O157:H7, Johannessen et al. (2005) transplanted lettuce seedlings into soil fertilized with manure inoculated with E. coli O157:H7. 
After $50 \mathrm{~d}$, the serotype was not detected in any parts of the lettuce leaves or roots; however, indigenous E. coli was detected sporadically on lettuce leaves. Islam et al. (2004) reported that survival of $S$. entercia in root vegetables persisted for several months after growth in manure composts. Based on these studies, it appears that there is a slight, but significant, increased risk of produce being contaminated with $E$. coli and other enteric bacteria when organic nutrient sources are used. However, contamination with the Ol57:H7 serotype resulting from use of organic nutrient sources does not appear to be a major concern.

\section{Conclusions}

The benefits of organic nutrient sources on soil physical, chemical, and biological properties are clearly evident from the literature, although careful management is necessary to avoid potential environmental impacts. Despite the benefits to soil quality, the effects of nutrient sources on crop yield and quality are less consistent. In part, this lack of consistency may be the result of the wide variability in rates and quality of the organic nutrient sources being studied. The fact that $\mathrm{N}$ is often limiting in organic systems can have profound impacts on the quality and taste of organic produce. Phytonutrient concentrations also are affected by differences in pest pressures. Because of the problems of avoiding confounding factors when comparing organic and conventional systems, it has been and will continue to be difficult to ascribe differences in soil and crop quality to specific nutrient sources. Future research should carefully document all variables as described in a recent article by Lester (2006). In addition, it should be recognized that the organic nutrient sources can vary significantly in terms of nutrient availability. Comparison of different organic nutrient sources or rates within an organic system may be more meaningful for determining impacts on soil and produce quality than comparison with conventional nutrient sources in a conventional system.

\section{Literature cited}

Allison, M.F., J.H. Fowler, and E.J. Allen. 2001. Responses of potato (Solanum tuberosum) to potassium fertilizers. J. Agr. Sci. 136:407-426.

Alsup, C.M., B.A. Kahn, and M.E. Payton. 2002. Using hairy vetch to manage soil phosphorus accumulation from poultry litter applications in a warm-season vegetable rotation. HortScience 37:490 495 .

Barker, A.V. 1975. Organic vs. inorganic nutrition and horticultural crop quality. HortScience 10:50-53.

Bourn, D. and J. Prescott. 2002. A comparison of the nutritional value, sensory qualities, and food safety of organically and conventionally produced foods. Crit. Rev. Food Sci. Nutr. 42:1-34.

Brandt, C.S. and K.C. Beeson. 1951. Influence of organic fertilization on certain nutritive constituents of crops. Soil Sci. 71:449-454.

Brandt, K. and J.P. Molgaard. 2001. Organic agriculture: Does it enhance or reduce the nutritional value of plant foods? J. Sci. Food Agr. 81:924-931.

Buck, J.W., R.R. Walcott, and L.R. Beuchat. 2003. Recent trends in microbiological safety of fruits and vegetables. Plant Health Progress doi: 10.1094/ PHP-2003-0121-01-RV. 18 Apr. 2007. http://www.apsnet.org/online/feature/ safety/top.asp.

Carbonaro, M., M. Mattera, S. Nicoli, P. Bergamo, and M. Cappelloni. 2002. Modulation of antioxidant compounds in organic vs. conventional fruit (peach, Prunus persica L., and pear Pyrus communis L.). J. Agr. Food Chem. 50:54585462.

Chen, L., W.A. Dick, J.G. Streeter, and H.A. Hoitink. 1998. Fe chelates from compost microorganisms improve $\mathrm{Fe}$ nutrition of soybean and oat. Plant Soil 200:137-147.

Chen, M.C. 2005. Organic fruits and vegetables: Potential health benefits and risks. Nutr. Noteworthy 7:Article 2.

Clark, M.S., W.R. Horwath, C. Shennan, and K.M. Scow. 1998. Changes in soil chemical properties resulting from organic and low-input farming practices. Agron. J. 90:662-671.

Clark, M.S., W.R. Horwath, C. Shennan, K.M. Scow, W.T. Lantni, and H. Ferris. 1999. Nitrogen, weeds and water as yield limiting factors in conventional lowinput, and organic tomato systems. Agr. Ecosystems Environ. 73:257-270.

Crews, T.E. and M.B. Peoples. 2004. Legume versus fertilizer sources of nitrogen: Ecological tradeoffs and human needs. Agr. Ecosystems Environ. 102:279-297.
Dale, M.F., D.W. Griffiths, H. Bain, and D. Todd. 1993. Glycoalkaloid increase in Solanum tuberosum on exposure to light. Ann. Appl. Biol. 123:411-418.

Dimitri, C. and C. Greene. 2002. Recent growth patterns in the U.S. Organic foods market. USDA Econ. Res. Serv., Agr. Info. Bul. 777.

Drinkwater, L.E., P. Wagoner, and M. Sarrantonio. 1998. Legume-based cropping systems have reduced carbon and nitrogen losses. Nature 396:262-265.

Dumas, Y., M. Dadomo, G. Di Lucca, and P. Grolier. 2003. Review: Effects of environmental factors and agricultural techniques on antioxidant content of tomatoes. J. Sci. Food Agr. 83:369-382.

Edmeades, D.C. 2003. The long-term effects of manures and fertilisers on soil productivity and quality: A review. Nutr. Cycling Agroecosystems 66:165-180.

Friedel, J.K. and D. Gabel. 2001. Nitrogen pools and turnover in arable soils under different durations of organic farming: I: Pool sizes of total soil nitrogen, microbial biomass nitrogen, and potentially mineralizable nitrogen. J. Plant Nutr. Soil Sci. 164:415-419.

Gaskell, M. and R. Smith. 2007. Organic nitrogen sources for vegetable crops. HortTechnology 17:xxx-xxx.

Goklany, I.M. 2002. The ins and outs of organic farming. Science 298:18891890.

Halvorson, A.D. and C.A. Reule. 2006. Irrigated corn and soybean response to nitrogen under no-till in northern Colorado. Agron. J. 98:1367-1374.

Hamner, K.C., L. Bernstein, and I.A. Maynard. 1945. Effects of light intensity, day length, temperature, and other environment factors on the ascorbic acid content of tomatoes. J. Nutr. 29:85-97.

Harwood, R.R. 1984. Organic farming research at the Rodale Research Center, p. 1-17. In: D.F. Bezdicek, J.F. Power, D.R. Keeney, M.J. Wright, D.M. Kral, and S.L. Hawkins (eds.). Organic farming: Current technology and its role in a sustainable agriculture. ASA, CSSA, SSSA, Madison, WI.

Heaton, S. 2001. Organic farming, food quality and human health. Soil Assn. Rpt., Bristol, UK.

Heeb, A., B. Lundegardh, T. Ericsson, and G.P. Savage. 2005. Nitrogen form affects yield and taste of tomatoes. J. Sci. Food Agr. 85:1405-1414.

Hornick, S.B. 1992. Factors affecting the nutritional quality of crops. Amer. J. Alternative Agr. 7:63-68. 
Hlywka, J.J., G.R. Stphenson, M.K. Sears, and R.Y. Yada. 1994. Effects of insect damage on glycoalkaloid content in potatoes (Solanum tuberosum). J. Agr. Food Chem. 42:2545-2550.

Islam, M., J. Morgan, M.P. Doyle, S.C. Phatak, P. Millner, and X. Jiang. 2004. Fate of Salmonella enterica Serovar Typhimurium on carrots and radishes grown in fields treated with contaminated manure composts or irrigation water. Appl. Environ. Microbiol. 70:24972502 .

Johannessen, G.S., G.B. Bengtsson, B.T. Heier, S. Bredholt, Y. Wasteson, and L.M. Rorvik. 2005. Potential uptake of Escherichia coli O157:H7 from organic manure into crisphead lettuce. Appl. Environ. Microbiol. 71:2221-2225.

Karlen, D.L. and D.E. Stott. 1994. A framework for evaluating physical and chemical indicators of soil quality, $\mathrm{p}$. 53-72. In: J.W. Doran, D.C. Coleman, D.F. Bezdicek, and B.A. Stewart (eds.). Defining soil quality for a sustainable environment. SSSA Special Publ. 35. Soil Sci. Soc. Amer., Madison, WI.

Kennedy, A.C. 1999. Microbial diversity in agroecosystem quality, p. 1-18. In: W.W. Collins and C.O. Qualset (eds.). Biodiversity in agroecosystems. CRC Press, Boca Raton, FL.

Kirchmann, H. and L. Bergstrom. 2001. Do organic farming practices reduce nitrate leaching? Commun. Soil Sci. Plant Anal. 32:997-1028.

Kirchmann, H. and M.H. Ryan. 2004. Nutrients in organic farming-Are there advantages from the exclusive use of organic manures and untreated minerals? p. 1-16. In: T. Fischer, N. Turner, J. Angus, L. McIntyeare, M. Robertson, A. Borrell, and D. Lloyd (eds.). New directions for a diverse planet. Proc. 4th Intl. Crop Sci. Congr., Regional Institute, Gosford, Australia.

Kramer, S.B., J.P. Reganold, J.D. Glover, B.J.M. Bohannon, and H.A. Mooney. 2006. Reduced nitrate leaching and enhanced denitrifier activity and efficiency in organically fertilized soils. Proc. Natl. Acad. Sci. USA 103:4522-4527.

Kuratomi, M. 2003. Assessing soil quality in alternative and conventional cropping systems. Univ. of Minnesota, St. Paul, MS Thesis.

Langmeier, M., E. Frossard, M. Kreuzer, P. Mader, D. Dubois, and A. Oberson. 2002. Nitrogen fertilizer value of cattle manure applied on soils originating from organic and conventional farming systems. Agonomie 22:789-800.
Larney, F.J., K.E. Buckley, X.Y. Hao, and W.P. McCaughey. 2006. Fresh, stockpiled, and composted beef cattle feedlot manure: Nutrient levels and mass balance estimates in Alberta and Manitoba. J. Environ. Qual. 35:18441854.

Leclerc, J., M.L. Miller, E. Joliet, and G. Rocquelin. 1991. Vitamin and mineral contents of carrot and celeriac grown under mineral or organic fertilization. Biol. Agr. Hort. 7:339-348.

Lester, G. 2006. Organic versus conventionally grown produce: Quality differences, and guidelines for comparison studies. HortScience 41:296-300.

Liebig, M.A. and J.W. Doran. 1999. Impact of organic production practices on soil quality indicators. J. Environ. Qual. 28:1601-1609.

Lockie, S., K. Lyons, G. Lawrence, and K. Mummery. 2002. Eating 'green': Motivations behind organic food consumption in Australia. Sociol. Ruralis 42:23-40.

Lombardi-Boccia, G., M. Lucarini, S. Lanzi, A. Aguzzi, and M. Cappelloni. 2004. Nutrients and antioxidant molecules in yellow plums (Prunus domestica L.) from conventional and organic productions: A comparative study. J. Agr. Food Chem. 52:90-94.

Loncarevic, S., G.S. Johannessen, and L.M. Rorvik. 2005. Bacteriological quality of organically grown leaf lettuce in Norway. Lett. Appl. Microbiol. 41:186-189.

Mader, P., A. Fliebach, D. Dubois, L. Gunst, P. Fried, and U. Niggli. 2002. Soil fertility and biodiversity in organic farming. Science 296:1694-1697.

Maga, J.A., F.D. Moore, and N. Oshima. 1976. Yield, nitrate levels and sensory properties of spinach as influenced by organic and mineral nitrogen fertilizer levels. J. Sci. Food Agr. 27:109-114.

Magdoff, F. 1991. Managing nitrogen for sustainable corn systems: Problems and possibilities. Amer. J. Alternative. Agr. $6: 3-8$.

Magdoff, F. and R. Weil. 2004. Soil organic matter management strategies, p. 45-65. In: F. Magdoff and R. Weil (eds.). Soil organic matter in sustainable agriculture. CRC Press, Boca Raton, FL.

Magkos, F., F. Arvaniti, and A. Zampelas. 2003. Organic food: Nutritious food or food for thought? A review of the evidence. Int. J. Food Sci. Nutr. 54:357371.

Maynard, D.N., A.V. Barker, P.L. Minotti, and N.H. Peck. 1976. Nitrate accumulation in vegetables. Adv. Agron. 28:71-118.
Mikkelsen, R. 2000. Nutrient management for organic farming: A case study. J. Natural Resources Life Sci. Educ. 29:8892.

Mikkelsen, R. 2007. Managing potassium for organic crop production. HortTechnology 17:455-460.

Montagu, K.D. and K.M. Goh. 1990. Effects of forms and rates of organic and inorganic nitrogen fertilizers on the yield and some quality indices of tomatoes (Lycopersicon esculentum Miller). N.Z. J. Crop Hort. Sci. 18:31-37.

Mukherjee, A., D. Speh, E. Dyck, and F. Diez-Gonzalez. 2004. Preharvest evaluation of coliforms, Escherichia coli, Salmonella, and Esherichia coli O157:H7 in organic and conventional produce grown by Minnesota farmers. J. Food Prot. 67:894-900.

Mukherjee, A., D. Speh, A.T. Jones, K.M. Buesing, and F. Diez-Gonzalez. 2006. Longitudinal microbiological survey of fresh produce grown by farmers in the upper Midwest. J. Food Prot. 69:19281936.

Nelson, N.O. and R.R. Janke. 2007. Phosphorus sources and management in organic production systems. HortTechnology 17:442-454.

Nilsson, T. 1979. Yield, storage ability, quality and chemical composition of carrot, cabbage and leek at conventional and organic fertilizing. Acta Hort. 93:209223.

Novak, J.M. and A.S.K. Chan. 2002. Development of P-hyperaccumulator plant strategies to remediate soils with excess P concentrations. Crit. Rev. Plant Sci. 21:493-509.

Oberholtzer, L., C. Dimitri, and C. Greene. 2005. Price premiums hold on as U.S. organic produce market expands. USDA Economic Res. Serv. VGS-30801 .

Palm, C.A., C.N. Gachengo, R.J. Delve, G. Cadisch, and K.E. Giller. 2001. Organic inputs for soil fertility management in tropical agroecosystems: Application of an organic resource database. Agr. Ecosystems Environ. 83:27-42.

Pang, X.P. and J. Letey. 2000. Organic farming: Challenge of timing nitrogen availability to crop nitrogen requirements. Soil Sci. Soc. Amer. J. 64:247-253.

Power, J.F. and J.W. Doran. 1984. N use in organic farming, p. 585-600. In R.D. Hauck (ed.). Nitrogen in crop production. ASA, CSSA, and SSSA, Madison, WI.

Pulleman, M., A. Jongmans, J. Marinissen, and J. Bouma. 2003. Effects of organic versus conventional arable farming on soil 
structure and organic matter dynamics in a marine loam in The Netherlands. Soil Use Mgt. 19:157-165.

Santamaria, P. 2006. Nitrate in vegetables: Toxicity, content, intake and EC regulation. J. Sci. Food Agr. 86:10-17.

Santamaria, P., A. Elia, and M. Gonnella. 2001. Ways of reducing rocket salad nitrate content. Acta Hort. 548:529-537.

Schutz, H.G. and O.A. Lorenz. 1976. Consumer preferences for vegetables grown under 'commercial' and 'organic' conditions. J. Food Sci. 41:70-73.

Sousa, C., P. Valentao, J. Rangel, G. Lopes, J.A. Pereira, F. Ferreres, R.M. Seabra, and P.B. Andrade. 2005. Influence of two fertilization regimens on the amounts of organic acids and phenolic compounds of tronchuda cabbage (Brassica oleracea L. Var. costata DC). J. Agr. Food Chem. 53:9128-9132.

Spargo, J.T., G.K. Evanylo, and M.M. Alley. 2006. Repeated compost application effects on phosphorus runoff in the Virginia piedmont. J. Environ. Qual. 35:2342-2351.

Stanford, G. and J.O. Legg. 1984. Nitrogen and yield potential, p. 263-272. In: R.D. Hauck (ed.). Nitrogen in crop production. Amer. Soc. Agron., Madison, WI.

Termine, E., D. Lairon, B. TaupierLetage, S. Gautier, R. Lafont, and H. Lafont. 1987. Yield and content in nitrates, minerals and ascorbic acid of leeks and turnips grown under mineral or organic nitrogen fertilizations. Plant Foods Hum. Nutr. 37:321-332.

Toor, R.K., G.P. Savage, and A. Heeb. 2006. Influence of different types of fertilisers on the major antioxidant components of tomatoes. J. Food Composition Anal. 19:20-27.

Torstensson, G., H. Aronsson, and L. Bergstrom. 2006. Nutrient use efficiencies and leaching of organic and conven- tional cropping systems in Sweden. Agron. J. 98:603-615.

Trewavas, A. 2004. A critical assessment of organic farming-and-food assertions with particular respect to the UK and the potential environmental benefits of no-till agriculture. Crop Prot. 23:757781 .

Uhland, R.E. 1947. Rotations in conservation, p. 527-536. In: A. Stefferud (ed.). Science in farming. The yearbook of agriculture 1943-1947. USDA, U.S. Govt. Printing Office, Washington, DC.

U.S. Department of Agriculture. 2000. National organic program. Final Rule. 7 CRF. Part 205. 18 Apr. 2007. http:// www.ams.usda.gov/nop/NOP/stand ards/FullText.pdf.

Vanlauwe, B., C. Gachengo, K. Sheperd, E. Barrios, G. Cadisch, and C.A. Palm. 2005. Laboratory validation of a resource quality-based conceptual framework for organic matter management. Soil Sci. Soc. Amer. J. 69:1135-1145.

Vogtmann, H., A.T. Temperli, U. Kunsch, M. Eichenberger, and P. Ott. 1984. Accumulation of nitrates in leafy vegetables grown under contrasting agricultural systems. Biol. Agr. Hort. 2:5168.

Williams, C.M. 2002. Nutritional quality of organic food: Shades of grey of shades of green? Proc. Nutr. Soc. 61:19-24.

Williams, P.R. and J.K. Hammitt. 2001. Perceived risks of conventional and organic produce: Pesticides, pathogens, and natural toxins. Risk Anal. 21:319330 .

Woese, K., D. Lange, C. Boess, and K.W. Bogl. 1997. A comparison of organically and conventionally grown foods-Results of a review of the relevant literature. J. Sci. Food Agr. 74:281-293.

Wolf, D.C. and G.H. Wagner. 2005. Carbon transformations and soil organic matter formation, p. 285-332. In: D.M. Sylvia, J.J. Furhrmann, P.G. Hartel, and D.A. Zuberer (eds.). Principles and applications of soil microbiology. Pearson Education, Upper Saddle River, NJ.

Worthington, V. 2001. Nutritional quality of organic versus conventional fruits, vegetables, and grains. J. Altern. Complement. Med. 7:161-173.

Wszelaki, A.L., J.F. Delwiche, S.D. Walker, R.E. Liggett, J.C. Scheerens, and M.D. Kleinhenz. 2005. Sensory quality and mineral and glycoalkaloid concentrations in organically and conventionally grown redskin potatoes (Solanum tuberosum). J. Sci. Food Agr. 85:720-726.

Yoder, R.E. 1937. The significance of the soil structure in relation to the tilth problem. Soil Sci. Soc. Amer. Proc. 2:21-33.

Young, J.E., X. Zhao, E.E. Carey, R. Welti, S. Yang, and W. Wang. 2005. Phytochemical phenolics in organically grown vegetables. Mol. Nutr. Food Res. 49:1136-1142.

Zebarth, B.J., Y. Leclerc, and G. Moreau. 2004. Rate and timing of nitrogen fertilization of Russet Burbank potato: Nitrogen use efficiency. Can. J. Plant Sci. 84:845-854.

Zhao, X., E.E. Carey, W. Wang, and C.B. Rajashekar. 2006. Does organic production enhance phyochemical content of fruit and vegetables? Current knowledge and prospects for research. HortTechnology 16:449-456.

Zhao, X., E.E. Carey, J.E. Young, W. Wang, and T. Iwamoto. 2007. Influences of organic fertilization, high tunnel environment, and postharvest storage on phenolic compounds in lettuce. HortScience 42:71-76.

Zvomuya, F., C.J. Rosen, and J.C. Miller. 2002. Response of Russet Norkotah clonal selections to nitrogen fertilization. Amer. J. Potato Res. 79:231-239. 